THE PAPERS OF MARTIN LUTHER KING, JR.

Initiated by

The King Center

in association with

Stanford University 


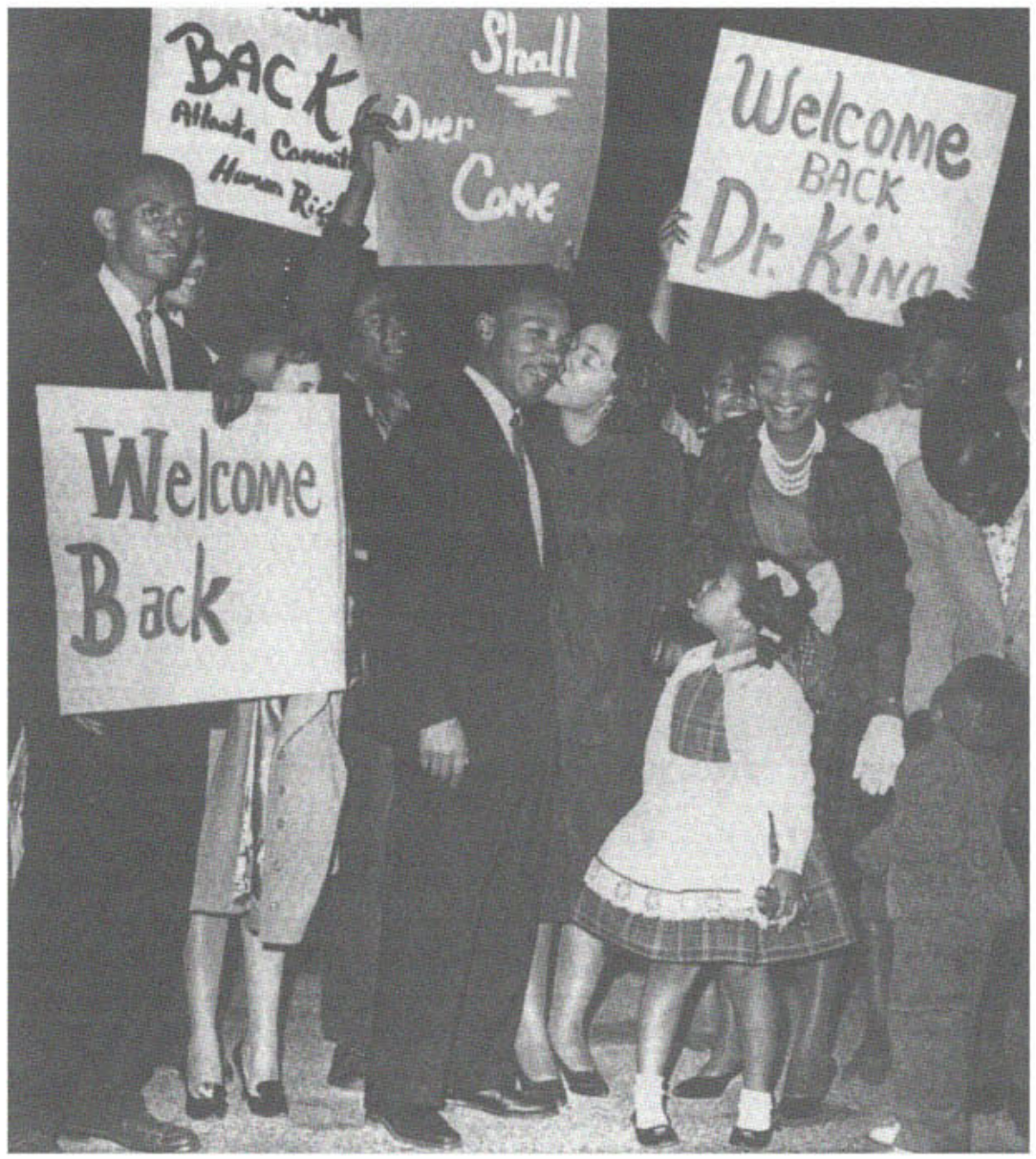

Upon his release from the Georgia State Prison at Reidsville, King is greeted by his wife, Coretta Scott King, his sister, Christine King Farris, and children Yolanda and Martin Luther King III on 27 October 1960. Courtesy of AP/Wide World Photos. 
THE PAPERS OF MARTIN LUTHER KING, JR.

\author{
VOLUME $\mathbf{v}$ \\ Threshold of a New Decade \\ January 1959-December 1960
}

\author{
Senior Editor \\ Clayborne Carson \\ Volume Editors \\ Tenisha Armstrong \\ Susan Carson \\ Adrienne Clay \\ Kieran Taylor
}

UNIVERSITY OF CALIFORNIA PRESS

Berkeley Los Angeles London 
University of California Press

Berkeley and Los Angeles, California

University of California Press, Ltd.

London, England

Writings of Martin Luther King, Jr., (C copyright $200_{5}$ by the Estate of Martin Luther King, Jr. Introduction, editorial footnotes, and apparatus ( copyright 2005 by the Martin Luther King, Jr., Papers Project. (C) copyright 2005 by the Regents of the University of California. All rights reserved. No part of this book may be used or reproduced in any manner whatsoever without written permission except in the case of brief quotations embodied in critical articles and reviews. For information, address queries as appropriate to:

Reproduction in print or recordings of the works of Martin Luther King, Jr.: the Estate of Martin Luther King, Jr., in Atlanta, Georgia.

All other queries: Rights Department, University of California Press, 2120 Berkeley Way, Berkeley, California 94704.

Library of Congress Cataloging-in-Publication Data

King, Martin Luther, Jr., 1929-1968.

The papers of Martin Luther King, Jr.

V. 5. Threshold of a new decade, January 1959-

December 1960.

Contents: V. 1. Called to serve, January 1929-June $195^{1-}$

V. 2. Rediscovering precious values, July $195^{1-N o v e m b e r ~} 1955-$

V. 3. Birth of a new age, December $1955^{- \text {December } 195^{6-}}$

V. 4. Symbol of the movement, January 1957 -December 1958 .

p. $\mathbf{c m}$.

Includes bibliographical references and index.

IS B N 0-520-24239-4 (cloth: alk. paper).

1. Afro-Americans-Civil rights. 2. Civil rights movementsUnited States-History-2oth century. 3. King, Martin Luther, Jr., 1929-1968-Archives. 4. United States-Race relations.

I. Carson, Clayborne, 1944- . II. Armstrong, Tenisha.

III. Carson, Susan. IV. Clay, Adrienne. V. Taylor,

Kieran. VI. Title.

E $185 \cdot 97 \cdot \mathrm{K}_{5} \mathrm{A2} \quad 2005$

$323^{\circ} \circ 2-$ dc2 2

Manufactured in the United States of America

$\begin{array}{lllll}23 & 22 & 21 & 20 & 19\end{array}$

9876543

The paper used in this publication meets the minimum requirements of ANSI/NISO Z39.48-1992 (R 1997) (Permanence of Paper). 0 
A civil rights crisis rocks the nation.

We are on the threshold of a new decade in which

the masses of Negro people are coming on to the stage of history and demanding their freedom now.

MARTIN LUTHER KING, JR., \& A. PHILIP RANDOLPH 9 June 1960 
The editors of the Martin Luther King, Jr., Papers Project wish to acknowledge the generosity of the following major contributors, without whose support this volume would not have been possible.

\section{Major Contributors}

Betty A. Williams Curtis and G. Russell Curtis, Sr.

The Flora and William Hewlett Foundation

Lilly Endowment Inc.

Ronnie Lott/All Stars Helping Kids

National Endowment for the Humanities

National Historical Publications and Records Commission

The Peninsula Community Foundation

Stanford University

Woodside Summit Group, Inc.

\section{Patrons}

A. Greg Crossfield

Bonnie Fisher and Boris Dramov

Leonard Merrill Kurz and the Kurz Family Foundation 


\section{Donors}

David and Susan G. Abernethy

Rabbi Sidney Akselrad, Congregation Beth Am

Bettina Aptheker

Herbert Aptheker

Sara and Harold Boyd

Harvey L. Cole

Nadine Cruz and Laurence Ulrich

Wayne Duckworth

Mary McKinney Edmonds

Candace Falk

George M. Fredrickson

Leola P. Graves

Lettie and Dr. Robert Green

Jenna Klein

Bernard and Kate B. Lafayette, Jr.

Ronald and Shoshana Levy

Patricia Margulies

Henry P. Organ

Mrs. Paprocki's Seventh Grade Social Studies Class,

Marie Murphy School, Wilmette, Illinois

Philadelphia Yearly Meeting of the Religious Society of Friends

Arnold Rampersad

Joan S. Reid

Viola M. C. White

Tyrone and Kim Willingham

Rosalind Wolf

Peter Zeughauser, the Zeughauser Group 